\title{
TINJAUAN PUSTAKA \\ PENGGUNAAN SILVER DIAMINA FLUORIDA (SDF) 38\% SEBAGAI Arresting Caries Treatment (ACT) PADA ANAK-ANAK
}

\author{
Lendrawati \\ Staf Fakultas Kedokteran Gigi Universitas Andalas \\ email : ellensyofyan@yahoo.com
}

\begin{abstract}
Abstrak
Karies merupakan masalah kesehatan gigi yang banyak diderita oleh anakanak seluruh dunia terutama negara berkembang termasuk Indonesia. Kerusakan gigi pada anak-anak terjadi lebih cepat dibandingkan orang dewasa karena gigi yang baru erupsi masih dalam proses maturasi dan proses mineralisasi belum sempurna. Tubuli dentin anak anak yang masih lebar menyebabkan pembentukan jaringan sklerotik tidak sempurna dan buffer saliva masih kurang sehingga aktivitas proteolitik menjadi lebih banyak di dalam mulut. Fluor merupakan zat mineral yang digunakan sebagai bahan yang efektif mencegah terjadinya karies gigi dapat membuat lapisan email tahan terhadap kerusakan yang disebabkan pelarutan email oleh zat asam. Strategi pencegahan karies lebih efektif sejak diperkenalkannya silver diamina fluoride (SDF) yang merupakan cairan tidak berwarna mengandung ion fluoride yang digunakan untuk memacu terjadinya proses remineralisasi hidoksiapatit mineral gigi. Penggunaan SDF ini merupakan metoda Arresting Caries Treatment (ACT). SDF menggabungkan efek penguatan gigi dari natrium fluoride $(\mathrm{NaF})$ dan efek nitrat perak.Konsentrasi efektif solusi SDF 38\% (44.800 ion fluoride ppm) digunakan untuk menghambat perkembangan karies pada gigi sulung anak-anak, terutama anak-anak yang sulit untuk dilakukan perawatan. SDF sederhana, mudah dalam mengaplikasikan dan biaya pemakaian lebih murah. SDF merupakan bahan yang tepat untuk digunakan untuk mengatasi masalah kesehatan gigi masyarakat terutama pada anak-anak.

Kata Kunci : karies gigi, silver diamine fluoride, Arresting Caries Treatment, topikal
\end{abstract}

\begin{abstract}
Dental caries is a health problem that affects many children all over the world, especially in developing countries, including Indonesia. Tooth decay in children occurs more rapidly than adults because the new tooth eruption is still in the process of maturation and mineralization process is not perfect. Dentin tubules of children is still wide lead sclerotic tissue formation was not perfect and still less saliva buffer so that a more proteolytic activity in the mouth. Fluor is a mineral substance that used as an ingredient that effectively prevent the occurrence of dental caries and can make enamel resistant to decay caused by acid dissolution email.
\end{abstract}


Strategy of caries prevention is more effective since the introduction of silver diamine fluoride (SDF) which is a colorless liquid containing fluoride ions are used to induce the process of remineralization mineral of tooth that is hidoksiapatit. SDF is a method of Arresting Caries Treatment (ACT). That combines the strengthening tooth effects of sodium fluoride $(\mathrm{NaF})$ and the effect of nitrate perak. Used of $38 \%$ concentration of SDF solution $(44,800 \mathrm{ppm}$ fluoride ion) are effective to inhibit the development of caries in primary teeth of children, especially children who are difficult to be treated. SDF use is simple, easy to apply and use costs cheaper. SDF is a good material to be used in the public dental health problems, especially in children.

Key word : dental caries, silver diamine fluoride, Arresting Caries Treatment, topical 


\section{Pendahuluan}

Masalah kesehatan gigi dan mulut yang banyak dijumpai pada anakanak di seluruh dunia terutama pada negara berkembang termasuk Indonesia adalah karies gigi. Karies merupakan suatu proses kronis dan regresif yang diawali dengan pelarutan email yang disebabkan oleh pembentukan substrat asam oleh mikroba yang akan menyebabkan terjadinya destruksi komponen organik gigi. Hasil penelitian menunjukkan bahwa $90 \%$ anak di Indonesia mengalami karies. Insidensi karies yang lebih parah pada daerah pedesaan dibandingkan di perkotaan dan terjadi pada anak-anak dari golongan ekonomi menengah ke bawah. Keadaan ini berpengaruh langsung pada derajat kesehatan anak yang masih dalam proses tumbuh kembang. ${ }^{(1.2)}$

Kerusakan gigi pada anak-anak terjadi lebih cepat dibandingkan dengan gigi orang dewasa, karena email gigi yang baru erupsi lebih mudah diserang karies karena proses maturasi belum sempurna disebabkan proses mineralisasi dan pengambilan flourida) yang masih berlangsung sampai 1 tahun setelah erupsi. Proses remineralisasi dapat terganggu dan pembentukan gigi menjadi tidak sempurna disebabkan oleh pola makan yang tidak sehat dan sering mengkonsumsi makanan manis dan lengket. Tubuli dentin anak anak yang masih lebar menyebabkan pembentukan jaringan sklerotik tidak sempurna dan buffer saliva masih kurang sehingga aktivitas proteolitik menjadi lebih banyak di dalam mulut. ${ }^{(3.4)}$

Fluor merupakan zat mineral yang digunakan sebagai bahan yang efektif mencegah terjadinya karies gigi dapat membuat lapisan email tahan terhadap kerusakan yang disebabkan pelaruta email oleh zat asam. Penggunaan fluor dapat diberikan secara sistemik maupun secara topikal.

Secara sistemik dapat dilakukan dengan pemberian tablet fluor dan melalui sumber air minum. Secara topikal dapat dilakukan dengan pemberian fluor pada gigi dengan cara pengulasan pada seluruh permukaan gigi, berkumur-kumur dengan larutan fluor dan diletakkan pada gigi dengan menggunakan sendok cetak khusus. Silver diamine fluoride(SDF) merupakan suatu tindakan Arresting Caries Treatment (ACT) untuk mengelola karies gigi yang tidak diobati pada anak-anak dan memberikan alternatif yang bisa diterapkan untuk mengelola karies dimana restorasi penuh tidak mungkin dilakukan. ${ }^{(5.6)}$

Cara kerja SDF merupakan prosedur non-invasif yang cepat dan mudah digunakan dalam menghentikan proses perkembangan karies gigi. Tidak ditemukan kerusakan pulpa yang parah setelah aplikasi SDF Keunggulan SDF dalam menghambat perkembangan karies mempunyai kelemahan dimana SDF dapat menyebabkan noda hitam pada gigi yang terserang karies dan juga memiliki rasa logam yang tidak menyenangkan dan tidak disukai oleh pasien, terutama anak-anak. Saat ini SDF dapat dijadikan bahan pilihan yang efektif dalam mencegah dan menghentikan perkembangan karies gigi terutama pada anak-anak yang masih kecil dan kurang kooperatif dalam perawatan. Hal ini dapat digunakan untuk menghambat perkembangan karies pada anak-anak, dan memungkinkan restorasi definitif yang akan dilakukan ketika mereka tumbuh dewasa. ${ }^{(5.7 .8)}$

Penurunan prevalensi dan keparahan karies gigi pada anak-anak selama beberapa dekade terakhir, namun belum menyentuh pada anakanak yang orang tuanyaberpenghasilan rendah terutama di negara berkembang. 
Karies gigi masih merupakan penyakit paling umum menyerang gigi anakanak. Silver diamine fluoride (SDF) telah digunakan untuk menghentikan karies gigi di banyak negara. Konsentrasi efektif $38 \%$ (44.800 ion fluoride ppm) solusi SDF dapat digunakan untuk menghentikan karies pada gigi sulung anak-anak, terutama anak-anak yang sulit untuk dilakukan perawatan. Perawatan karies menggunakan SDF ini sederhana mudah dalam mengaplikasikan dan biaya pemakaian lebih murah, hal ini menunjukkan bahwa SDF merupakan bahan yang tepat untuk digunakan untuk mengatasi masalah kesehatan gigi masyarakat terutama pada anak-anak. ${ }^{(6,}$ 9)

\section{Pembahasan}

\section{Karies Gigi}

Karies gigi masih merupakan penyakit yang paling umum dan membutuhkan perhatian lebih terutama pada anak-anak. Proses terjadinya karies diawali dengan pelarutan email gigi yang disebabkan oleh pembentukan substrat asam oleh mikroba sehingga terjadi destruksi komponen organik gigi. Proses demineralisasi terjadi bila $\mathrm{pH}$ saliva turun menjadi di bawah 5,5 sehingga proses demineralisasi menjadi lebih cepat daripada proses remineralisasi, hal ini menyebabkan lebih banyak mineral gigi yang larut dalam kondisi asam dan membuat lubang pada gigi yang tidak dapat diperbaiki kembali oleh tubuh. Kepadatan kristal email sangat menentukan kelarutan email, semakin banyak email mengandung mineral maka kristal email semakin padat dan email akan semakin resisten terhadap kerusakan demikian juga sebaliknya. ${ }^{(8.10 .11)}$

Adanya plak menyebabkan demineralisasi dan menghambat remineralisasi yang mengurangi kekua- tan struktur gigi. Fluoride mempunyai struktur kristal lebih tahan terhadap tantangan asam dari bakteri dengan demikian proses inisiasi dan progression karies dapat dihambat. Strategi pencegahan karies yang lebih efektif sejak diperkenalkannya silver diamina fluoride (SDF) yang merupakan cairan tidak berwarna mengandung ion fluoride yang digunakan untuk memacu terjadinya proses remineralisasi hidoksiapatit mineral gigi. Gigi sulung lebih mudah terjadi karies dibandingkan gigi tetap karena gigi sulung mengandung lebih banyak bahan organik dan air dari pada kandungan mineral. Mineralisasi gigi sulung terjadi dalam jangka waktu 1 tahun sedangkan pembentukan dan mineralisasi gigi tetap 7-8 tahun. Saliva dapat meremineralisasi karies yang masih dini karena banyak mengandung ion kalsium dan fosfat. Kemampuan saliva dalam melakukan proses remineralisasi meningkat jika terdapat banyak ion fluor. ${ }^{(4.10 .11)}$

\section{Silver Diamine Fluorida}

Penggunaan senyawa silver nitrat menurut Halsted telah dimulai sejak tahun 1890 yang lalu sebagai aplikasi anti infeksi meliputi penutup luka bakar akut, lapisan kateter, sistem pemurnian air, sterilisasi gaun rumah sakit, bahan penjahitan bedah dan pencegahan penyakit infeksi. Penggunaan senyawa silver diamin fluoride sebagai bahan pengobatan gigi dimulai tahun 1960 di Yamaga Jepang. Silver Diamin Fluoride digunakan sebagai bahan efektif mencegah karies aktif di Jepang dan negara-negara lain di Asia juga Australia dan Amerika Selatan untuk jangka waktu yang cukup lama. Kemampuan $\mathrm{Ag}^{+}$untuk membunuh organisme patogen pada konsentrasi $<50$ ppm. ${ }^{(7.5)}$ 
Silver diamine fluoride bakteri dan asam nukleat untuk (SDF) telah digunakan untuk membentuk asam amino dan nukleat menghambat perkembangan karies gigi perak, yang mampu melakukan di banyak negara. SDF merupakan metabolisme yang diperlukan dan perawatan karies yang sering disebut reproduksi fungsi hidup bacteria. juga dengan metoda Arresting Caries Terhambatnya pertumbuhan bakteri dan Treatment (ACT) dimana pengelolaan penghambatan pembentukan biofilm, karies gigi pada anak-anak diobati maka perkembangan karies terhambat. hanya dengan menghentikan proses Pada proses pembusukan, SDF bereaksi perkembangan karies. Dengan kon- dengan HA untuk membentuk FA, dan sentrasi 38\% (44.800 ion fluoride ppm) produk sampingan perak fosfat. Pengsolusi SDF umumnya digunakan untuk gunaan SDF terbukti sukses dalam menghentikan karies pada gigi sulung menghentikan proses karies pada anak-anak, terutama anak-anak yang sejumlah uji klinis, dengan tidak ada masih muda dan sulit untuk dilakukan laporan terjadinya komplikasi. SDF perawatan. Penggunaan SDF untuk adalah produk dengan manfaat menghentikan karies gigi merupakan kesehatan potensial masyarakat karena prosedur non-invasif yang cepat dan mudah digunakan. Pengaplikasian SDF ternyata dapat menyebabkan noda hitam pada gigi karies disebabkan kandungan perak didalamnya, selain itu SDF juga memiliki rasa logam tidak menyenangkan yang tidak disukai oleh pasien. Beberapa laporan hasil studi terhadap SDF tidak menemukan kerusakan pulpa yang parah setelah aplikasi. ${ }^{(6.8)}$
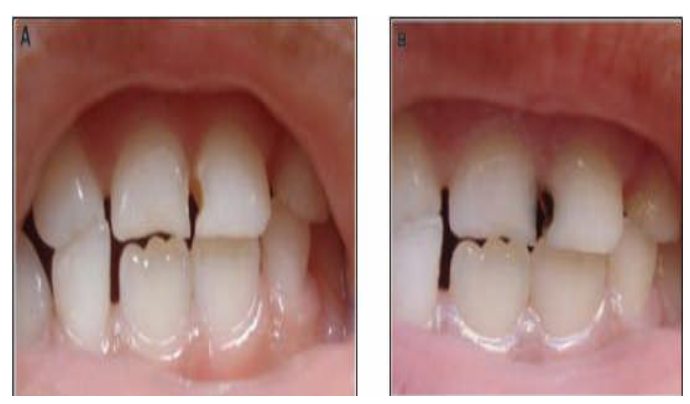

Gambar 1. Perubahan warna gigi yang terjadi setelah aplikasi SDF (sumber : Richard Niederman 2010)

SDF menggabungkan efek penguatan gigi dari natrium fluoride $(\mathrm{NaF})$ dan efek nitrat perak. Sodium fluoride bereaksi dengan hidroksi apatit (HA) untuk membentuk fluorapatite (FA) yang lebih tahan terhadap pembusukan. Perak nitrat bereaksi dengan kelompok tiol dari amino memungkinkan untuk pengobatan dan pencegahan pada saat yang sama, mudah untuk diaplikasikan dan cara menerapkan, non-invasif. Hanya dibutuhkan pelatihan yang minimal dan tidak mahal. Selain itu SDF dapat menjadi pilihan pengobatan yang tepat untuk anak-anak. ${ }^{(7.5 .12)}$

Penelitian yang dilakukan di Nepal untuk melihat efektifitas SDF dengan membagi empat kelompok perlakuan yaitu, pertama kelompok menerima aplikasi tunggal $38 \%$ SDF, kedua mendapat 38\% SDF dengan asam tanat, kelompok ketiga mendapat $12 \%$ SDF dan kelompok keempat tidak menerima SDF sama sekali. Dilakukan pengamatan setelah aplikasi SDF selama enam bulan, satu tahun, dan dua tahun. Haasil penelitian ini menunjukkan SDF dengan konsentrasi 38\% dapat menghentikan karies. Para peneliti menyarankan agar SDF digunakan untuk menghentikan perkembangan karies untuk negara-negara miskin dan daerah terpencil di mana tidak mungkin dilakukan perawatan sempurna dan tiadanya biaya untuk memulihkan penyakit karies gigi. ${ }^{(10.13)}$

Tahun 2002 Edward meneliti sifat dan efektivitas silver diamin 
fluoride pada anak-anak maupun pada orang dewasa. Digunakan untuk pencegahan dan pilihan pengobatan dalam pengelolaan karies. Aplikasi topikal perak diamina fluoride terbukti sangat efektif dalam menghentikan proses terjadinya karies gigi. Edward lo membandingkan SDF dan pernis fluoride untuk lebih memahami mekanisme kerja SDF, hasil penelitiannya menunjukkan bahwa fraksi tertinggi pernis fluoride yang mencegah penghentian dan pencegahan karies adalah $21,3 \%$ dan SDF adalah 55,7\%. Hasil ini menunjukkan bahwa SDF lebih efektif daripada pernis fluoride. Selain itu, ketersediaan bahan SDF dalam menghambat karies dan pencegahan yang aman, efektif, efisien, dan merata diharapkan dapat memenuhi kriteria dari WHO dalam mencapai tujuan Milenium untuk perawatan medis abad ke-21. ${ }^{(6.14)}$

\section{Cara Kerja Silver Diamine Fluorida}

Menurut suatu studi di Annals of cicrobiology clinic dan antimicroba Silver diamine fluoride dapat menghentikan karies gigi dengan cara mengurangi proses demineralisasi dan menghambat pertumbuhan biofilm kariogenik multispecies. Sebuah tim peneliti dari university of Hong Kong dan Anhui Medical University menggunakan mulut buatan yang dikendalikan komputer untuk mempelajari pengaruh $38 \%$ SDF pada biofilm kariogenik dan dentin lesi karies, hasil studi klinis ini menunjukkan bahwa SDF efektif dalam melindungi dentin dan menghentikan karies. Ion silver dan ion fluoride yang dilepaskan dari SDF menghambat pembentukan biofilm kariogenik, dimana endapan yang mengandung silver tinggi dan kadar fosfor masuk ke lubang tubulus yang telah aplikasi SDF dan membantu meminimalkan kehilangan mineral.
Para peneliti juga menemukan bahwa SDF memiliki efek penghambatan pada metaloproteinase matriks, yang memainkan peran penting dalam kerusakan kolagen pada lesi karies. ${ }^{(5.11)}$ SDF telah digunakan untuk mengelola karies, khususnya, pada pasien dengan prevalensi karies yang tinggi. Kesederhanaan aplikasi SDF memungkinkan penggunaannya pada anak-anak dengan mengurangi proses demineralisasi, meminimalkan hilangnya kandungan mineral, dan memperlambat kehancuran kolagen. ${ }^{(7.12)}$

Pengaruh terhadap kesehatan garam silver khususnya $\mathrm{AgNO}^{3}$ yang mematikan terjadi dalam konsentrasi hingga 2gr. Senyawa perak dapat perlahan diserap oleh jaringan tubuh, menyebabkan pigmentasi kulit menjadit kebiruan atau kehitaman (argiria). Bila terjadi kontak mata dapat menyebabkan cedera kornea. Kontak berulang dan berkepanjangan pada kulit dapat menyebabkan dermatitis alergi. Apabila terhirup uap silver pada konsentrasi tinggi dapat menyebabkan pusing, sesak nafas, sakit kepala atau iritasi pernapasan. Konsentrasi yang sangat tinggi dapat menyebabkan kantuk, kebingungan, kejang, pingsan, koma atau kematian. ${ }^{(10.15)}$

\section{Kesimpulan}

SDF merupakan suatu terapi baru yang lebih terjangkau dan efektif yang diperlukan untuk membantu mengurangi prevalensi karies pada anak-anak. Efek anti karies SDF 38\% secara topikal efektif menghambat perkembangan karies. Masih perlu dilakukan studi lebih jauh untuk menilai efek jangka panjang dan untuk mengatasi masalah pewarnaan hitam sebelum rekomendasi yang jelas dapat di ungkapkan mengenai penggunaan potensinya lebih jauh. Ion silver dan ion fluoride yang dilepaskan dari SDF 
menghambat pembentukan biofilm kariogenik, dimana endapan yang mengandung silver tinggi dan kadar fosfor masuk ke lubang tubulus yang telah aplikasi SDF dan membantu meminimalkan kehilangan mineral. Para peneliti juga menemukan bahwa SDF memiliki efek penghambatan pada metaloproteinase matriks, yang memainkan peran penting dalam kerusakan kolagen pada lesi karies. SDF merupakan perawatan karies disebut juga dengan metoda Arresting Caries Treatment (ACT) dimana mengelola karies gigi pada anak-anak diobati hanya dengan menghentikan proses perkembangan karies. Metoda ACT dengan $38 \%$ SDF memberikan alternatif ketika pengobatan restoratif untuk gigi primer tidak dapat dilakukan. Terutama di negara berkembang di mana perawatan gigi sulit dilaksanakan dan risiko karies masih tinggi sementara tenaga kesehatan gigi masih belum memadai.

\section{KEPUSTAKAAN}

1. Depkes RI,2008, Riset Kesehatan Dasar, Bppk., Depkes RI, Jakarta.

2. Sriyono, N.W., 2009, Pengantar Ilmu Kedokteran Gigi Pencegahan, Cetakan Ke3, Medika Fakultas Kedokteran Ugm, Jogjakarta.

3. Summit, James B., J. William Robbins, and Richard S. Schwartz. "Fundamentals of Operative Dentistry: A Contemporary Approach." 2nd edition. Carol Stream, Illinois, Quintessence Publishing Co, Inc, 2001, p. 30. ISBN 0-86715382-2.
4. Ash, Nelson, "Wheeler's Dental Anatomy, Physiology, and Occlusion." 8th edition. Saunders, 2003, p. 13. ISBN 07216-9382-2.

5. Chu $\mathrm{CH}$, Lo EC. Promoting caries arrest in children with silver diamine fluoride: A review. Oral Health Prev Dent 2008; 6(4):315-21.

6. Holmgren, A., Mulder, J., Walker, D., et.al Efficacy of Silver Diamine Fluoride for Arresting Caries Treatment $J$ DENT RES, July 2009; vol. 88, 7: pp. 644-647.

7. Alice Chen, BSc; Mary Cho, BSc; Sari Kichler, BSc, MSc;Jeffrey Lam, BSc, MSc; Anum Liaque, BSc; Sobia Sultan, BSsc, MScJCDA Silver Diamine Fluoride: An Alternative to Topical Fluorides - www.cda-adc.ca/jcda • April 2011, Vol. XX, No. X•

8. Edward CM Non-invasive caries management - with special emphasis on recent research and clinical experiences with Silver Diamine Fluoride Dental Public Health, University of Hong Kong, Hong Kong. 2010.

9. Mei L, Chu CH, Samaranayake $L P$ \& Lo ECM. Fluoride concentrations and acidity of silver diamine fluoride solutions for dental use. International Journal of Paediatric Dentistry 2011: 1-7. doi:10.1111/ipd.12005 
10. Niederman R., Silver Diamina Flouride, ADA symposium on Early Chilhood Caries in American Indian Children, 2010.

11. 11.Mei L, Li Q-L, Chu CH, Lo ECM \& Samaranayake LP. Antibacterial effects of silver diamine fluoride on multispecies cariogenic biofilm on caries. Annuals of Clinical Microbiology and Antimicrobials 2010; 12:4 : 1-7. doi:10.1186/1476-0711-12-4

12. Rosenblatt, A., Stamford, T., Niederman, R., Silver Diamine Fluoride: A Caries "SilverFluoride Bullet" $J$ DENT RES February 2009 88: 116-125.
13. Kathy Kincade Silver diamine fluoride (SDF) arrests dental caries by reducing the demineralization process and inhibiting the growth of multispecies cariogenic biofilms, according to a new study in Annuals of Clinical Microbiology and Antimicrobials (February 26, 2010).

14. Yee R., Holmgren, C., Efficacy of Silver Diamine Fluoride for Arresting Caries.

15. Treatment Journal of Dental Research 91:753---758.

16. Bicuspid, 2009, Silver diamine found effective for caries Journal of Dental Research (July 2009, Vol. 88:7, pp. 644647). 